\title{
HEARING LOSS IN BLAST TRAUMA VICTIMS. A MULTICENTRE RETROSPECTIVE STUDY
}

\author{
Kamran Ashfaq Ahmed Butt, Naeem Riaz Bhalli, Wasif Siddique*, Attique Ahmed**, Maryam Khan***, \\ Manzoor Ahmed****
}

Combined Military Hospital Gujranwala/National University of Medical Science (NUMS) Pakistan, *Combined Military Hospital Malir/ National University of Medical Science (NUMS) Pakistan, ${ }^{* *}$ Combined Military Hospital/National University of Medical Science (NUMS)

Rawalpindi Pakistan, ${ }^{* * *}$ Combined Military Hospital Lahore/National University of Medical Science (NUMS) Pakistan, ${ }^{* * * *}$ Combined Military Hospital Kharian/National University of Medical Science (NUMS) Pakistan

\begin{abstract}
Objective: To describe the resultant Otologic morbidity and report on the early outcomes following blasts occurring in twin cities of Quetta and Peshawar.

Study Design: Case series.

Place and Duration of Study: ENT department Tertiary Care Centre Quetta and Tertiary Care Hospital Peshawar. Study period was, from Jan 2013 to Dec 2013.

Methodology: All bomb blast patients brought to the hospitals were included in study. Participants completed Symptom Assessment Forms followed by detailed ENT examination and Pure Tone Audiograms on arrival and after 6 weeks.

Results: A total of 504 patients were included initially of which $80 \%$ of the patients were male. About $57.8 \%$ of the patients complained of ear injury, $21.6 \%$ of the total patients had tympanic membrane perforation on initial presentation. Chances of spontaneous closure of perforation were $20.9 \%$ in our study. Chances of hearing improvement were $17.9 \%$ in our study at the end of the study period.

Conclusion: Blast related otologic injuries constituted a major source of morbidity The most common type of hearing loss following a blast trauma was mild to moderate conductive type. Chances of recovery of hearing following blast do exist (17.9\%). Suspected patients should be regularly assessed and followed up. Much work needs to be done to study the impact of blast trauma on hearing in our country.
\end{abstract}

Keywords: Blast Injuries, Hearing loss, Otologic disease, Tympanic membrane perforation.

This is an Open Access article distributed under the terms of the Creative Commons Attribution License (http://creativecommons.org/licenses/by/4.0), which permits unrestricted use, distribution, and reproduction in any medium, provided the original work is properly cited.

\section{INTRODUCTION}

Pakistan has been on the receiving end of bomb attacks in the recent years. This has resulted in massive loss of lives as a result of an incessant spate of bombings on civilian populations. These terrorist activities not only disrupt the lives of innocent people but at the same time leave them with permanent psychological and physical scars $^{1}$. Limited local studies have been done to observe the effects of blast exposure on unprotected ears and the chances of recovery in the exposed individuals.

Whenever an explosive detonates, high pressure gases are released that expand away from the point of detonation. This compresses the sur-

Correspondence: Dr Kamran Ashfaq Ahmed Butt, ENT Specialist, Combined Military Hospital, Gujranwala Pakistan

Received: 27 Dec 2016; revised received: 26 Oct 2019; accepted: 06 Nov 2019 rounding ear and produces both blast wave and a blast wind that propagates away in a spherical pattern. Damage to the ear is one of the most common sequelae of blast exposure. This is because ear is extremely susceptible to air pressure waves or blast caused by explosion. However the degree of damage done depends on the strength of the explosion and the distance from the explosion site. An explosion occurring indoors creates reflecting waves causing more damage ${ }^{2-4}$.

Bodily damage caused by blast exposure occurs in four ways. A primary blast injury; caused by the direct effect of the high pressure wave on the tissues. Secondary blast injuries caused by the fragments or debris propelled by the blast wind. Tertiary blast injury caused by blast wind knocking or blowing an individual into a solid object and quaternary blast injury which includes 
all other effects such as post traumatic stress disorder and burns. Damage to the tympanic membrane is a primary blast injury ${ }^{4-7}$. Air containing viscera such as lungs and abdomen are the other organs which are sensitive to primary blast injury. Ear drum rupture can occur at pressures as low as $35 \mathrm{KPa}$ while $105 \mathrm{Kpa}$ pressure causes perforation in $50 \%$ of ear drums in adults. Presence of wax in ear canal is believe to afford some protection to the ear drum during blast trauma. Lungs and abdomen require considerably higher pressures to be injured. Therefore in any blast victim lesion of the ear drum should always be looked out for ${ }^{3,7,8}$. The purpose of this retrospective study was to describe the resultant Otologic morbidity and report on the early outcomes following blasts occurring in Quetta and Peshawar in 2013.

\section{METHODOLOGY}

This was a retrospective study carried out in ENT Departments of Tertiary Care Hospitals of Quetta and Peshawar from Jan to Dec 2013. Sampling method was universal sampling. Data was collected of all victims of bomb blast injuries brought to Tertiary Care Hospital of Quetta and Peshawar during the period of study and included. A total of 504 Patients were initially screened using the Patient Assessment Form for presence of symptoms related to otologic trauma. They were then examined by an ENT consultant and baseline PTA for hearing assessment was performed. Patients with perforated tympanic membranes were advised care of tympanic membrane and repeated visits to prevent secondary infection. After 6 weeks a second PTA was performed to determine the hearing levels. Inclusion criteria of the study were: All civilian patients of bomb blast trauma admitted to hospital Quetta and Peshawar during the period of study.

The exclusin cirteria of this study was to patients who were seriously injured, On ventilatory support, Non communicating. Patients, Children below 8 years of age, Patients with prior history of hearing loss, ear discharge or tinnitus, Patients with associated medical conditions inclu- ding diabetes mellitus, anemia and cardiovascular disorders like ischemic heart disease, hypertension and carotid artery stenosis. Data collection was done on the following lines: Permission was sought from Hospital Ethical Committee. Records of all the patients admitted following the blasts were checked. Informed written consent was taken from all the patients. Hospital registration number, name, gender, age, address and phone number were noted for future communication. Patients were initially screened by a simple questionnaire regarding the presence of any symptoms of hearing loss. Following positive response on the Questionnaire Performa detailed ENT examination was performed. PTA with air conduction levels at the frequencies of 500.1000. 2000 and $4000 \mathrm{~Hz}$ was performed initially and repeated after 6 weeks. Hearing loss was categorized as. Normal $<15 \mathrm{db}$, Slight 16-25, Mild 26-40, Moderate 41-55, Moderately Severe 56-70, Severe 71-90, Profound $>90 \mathrm{db}$.

Data analysis was done using SPSS Version 16. The variables to be analyzed included quantitative data like age which were analyzed as mean and standard deviation. Qualitative data like gender, perforation and degree of hearing loss initially and at 6 weeks were presented as frequency and percentage. Chi square and Fischer exact test was done. The $p$-value $\leq 0.05$ was taken as significant.

\section{RESULTS}

A total of 336 civilian victims of bomb blast trauma were brought to the hopital in Quetta during the period of study. During the same period 168 blast trauma victims were admitted at Peshawar Centre. Among them 28 patients in Quetta and 5 in Peshawar were severely injured and unable to complete the questionnaire. Fourteen patients in Quetta and ${ }^{12}$, in Peshawar were very young or children less the 8 years. Twenty one in Quetta and 9 in Peshawar had previous history of hearing loss or ear diseases like CSOM which rendered their findings inconclusive. Thirty one patients in Quetta and 13 in Peshawar had HTN/DM or similar chronic illnesses, while 
the numbers of patients without any complaints of hearing loss were 54 and 26 in Quetta and Peshawar respectively. Therefore the patients included in the study were 188 from Quetta and 103 from Peshawar.

Table-I: Status of tympanic membrane in both groups.

\begin{tabular}{|c|c|c|c|c|}
\hline & \multicolumn{2}{|c|}{ Hospital } & \multirow{2}{*}{$\begin{array}{c}p \text { - } \\
\text { value }\end{array}$} \\
\hline & & Quetta & Peshawar & \\
\hline \multirow{2}{*}{$\begin{array}{l}\text { Perforation } \\
\text { Left Ear } \\
\text { Initially }\end{array}$} & Yes & $64(34 \%)$ & $46(44.7 \%)$ & \multirow[b]{2}{*}{0.074} \\
\hline & No & $124(66 \%)$ & $57(55.3 \%)$ & \\
\hline \multirow{2}{*}{$\begin{array}{l}\text { Perforation RT } \\
\text { Ear Initially }\end{array}$} & Yes & $71(37.8 \%)$ & $37(35.9 \%)$ & \multirow{2}{*}{0.75} \\
\hline & No & $117(62.2 \%)$ & $66(64.1 \%)$ & \\
\hline \multirow{2}{*}{$\begin{array}{l}\text { Perforation } \\
\text { Left Ear at } 6 \\
\text { Weeks }\end{array}$} & Yes & $53(57.6 \%)$ & $39(42.4 \%)$ & \multirow[b]{2}{*}{0.09} \\
\hline & No & $\begin{array}{c}135 \\
(67.8 \%) \\
\end{array}$ & $64(32.2 \%)$ & \\
\hline \multirow{2}{*}{$\begin{array}{l}\text { Perforation RT } \\
\text { Ear at } 6 \text { Weeks }\end{array}$} & Yes & $58(70.7 \%)$ & $24(29.3 \%)$ & \multirow{2}{*}{0.17} \\
\hline & No & $130(62.2 \%)$ & $79(37.8 \%)$ & \\
\hline
\end{tabular}

hearing loss. The frequency of hearing loss in each individual category in either of the ears in both departments (table-II). Twenty four (17.78\%) tympanic membranes had spontaneous closure of perforation at six weeks in Quetta group while $20(24.09 \%)$ tympanic membranes healed spontaneously from Peshawar group. Thirty six patients $(19.2 \%)$ showed improved hearing at the end of six weeks in Quetta group while 17 patient's $(16.5 \%)$ hearing improved at the end of six weeks in Peshawar group. The results from both hospitals show that mild and moderate degree of conductive hearing loss was the most common type of loss in blast trauma victims irrespective of the fact whether their tympanic membrane was intact or not. Profound hearing loss was less than $1 \%$ overall (fig-1 \& 2 ).

Table-II: Hearing status at initial presentation and after six weeks.

\begin{tabular}{|c|c|c|c|c|c|c|c|c|c|}
\hline & & $\begin{array}{c}\text { Normal } \\
\text { Hearig } \\
\text { n ( } \%)\end{array}$ & $\begin{array}{c}\text { Slight } \\
\text { HL } \\
\text { n (\%) }\end{array}$ & $\begin{array}{l}\text { Mild HL } \\
\text { n (\%) }\end{array}$ & $\begin{array}{l}\text { Mod.hl } \\
\text { n (\%) }\end{array}$ & $\begin{array}{c}\text { Mod. } \\
\text { Sev. HL. } \\
\text { n (\%) }\end{array}$ & $\begin{array}{l}\text { Sev.HL } \\
\text { n ( } \%)\end{array}$ & $\begin{array}{c}\text { Profound } \\
\text { HL } \\
\text { n (\%) }\end{array}$ & $\begin{array}{c}p \text { - } \\
\text { value }\end{array}$ \\
\hline $\begin{array}{l}\text { Hospital } \\
\text { Quetta }\end{array}$ & $\begin{array}{l}\text { Hearing RT Ear } \\
\text { Initially }\end{array}$ & $55(59.8)$ & $22(71)$ & $41(64.1)$ & 46 (69.7) & 17 (68) & $4(44.4)$ & $3(75)$ & \multirow{2}{*}{0.65} \\
\hline $\begin{array}{l}\text { Hospital } \\
\text { Peshawer }\end{array}$ & $\begin{array}{l}\text { Hearing RT Ear } \\
\text { Initially }\end{array}$ & $37(40.2)$ & 9 (29) & $23(35.9)$ & $20(30.3)$ & $8(32)$ & 5 (55.6) & $1(25)$ & \\
\hline $\begin{array}{l}\text { Hospital } \\
\text { Quetta }\end{array}$ & $\begin{array}{l}\text { Hearing LT Ear } \\
\text { Initially }\end{array}$ & $60(63.2)$ & $19(6.4)$ & 45 (72.6) & 48 (59.3) & $8(50)$ & 8 (57.1) & - & \multirow{2}{*}{0.087} \\
\hline $\begin{array}{l}\text { Hospital } \\
\text { Peshawer }\end{array}$ & $\begin{array}{l}\text { Hearing LT Ear } \\
\text { Initially }\end{array}$ & $35(36.8)$ & 3 (13.6) & 17 (27.4) & 33 (40.7) & $8(50)$ & $6(42.9)$ & 1 (100) & \\
\hline $\begin{array}{l}\text { Hospital } \\
\text { Quetta }\end{array}$ & $\begin{array}{l}\text { Hearing RT Ear } \\
\text { At } 6 \text { Weeks }\end{array}$ & $60(60)$ & $22(61.1)$ & $54(69.2)$ & 36 (70.6) & $11(64.7)$ & $3(50)$ & $2(66.7)$ & \multirow{2}{*}{0.782} \\
\hline $\begin{array}{l}\text { Hospital } \\
\text { Peshawer }\end{array}$ & $\begin{array}{l}\text { Hearing RT Ear } \\
\text { AT } 6 \text { Weeks }\end{array}$ & $40(40)$ & $14(38.9)$ & $24(30.8)$ & $15(29.4)$ & $6(35.3)$ & $3(50)$ & $1(33.3)$ & \\
\hline $\begin{array}{l}\text { Hospital } \\
\text { Quetta }\end{array}$ & $\begin{array}{l}\text { Hearing LT Ear } \\
\text { AT } 6 \text { Weeks }\end{array}$ & $61(62.9)$ & $25(69.4)$ & $56(77.8)$ & $39(58.2)$ & $3(25)$ & $4(57.1)$ & - & \multirow{2}{*}{0.008} \\
\hline $\begin{array}{l}\text { Hospital } \\
\text { Peshawer }\end{array}$ & $\begin{array}{l}\text { Hearing LT Ear } \\
\text { AT } 6 \text { Weeks }\end{array}$ & 36 (37.1) & $11(30.6)$ & $16(22.2)$ & $28(41.8)$ & $9(75)$ & $3(42.9)$ & - & \\
\hline
\end{tabular}

Key: slight hl: slight hearing loss 16-25, mild hl: mild hearing loss 26-40, mod.hl: moderate hearing loss 41-55, mod.sev.hl: moderate severe hearing loss 56-70, sev.hl: severe hearing loss 71-90, profound hl: profound hearing loss $>90 \mathrm{db}$.

One hundred and forty two patients $(75.5 \%)$ from Quetta and 87 (84.5\%) from Peshawar were male. Mean age was $30.83 \pm 14.17$ in Quetta and $35.45 \pm 12.39$ in patients of Peshawar. One hundred and thirty five tympanic membranes $(35.9 \%)$ were perforated in patients from Quetta while 83 tympanic membranes (40.3\%) from Peshawar were perforated on examination initially (table-I). Hearing loss was grouped in 7 categories ranging from normal hearing to profound

\section{DISCUSSION}

Earliest reports on hearing loss as a result of excessive stimulation of inner ear were made in $1872^{8-10}$. This stimulation can be due to various form of sound exposure. Recently exposure to blasts has represented a common cause of damage to ear. A study conducted in US found total annual expense of hearing health care services to veterans for hearing impairment exceeded $\$ 1$ billion11 Pakistan had more than 600 bomb blasts 
in year 2013 resulting in significant hearing morbidity $^{12}$. Little work has been done in our region to effectively gauge the hearing morbidity associated with blasts.

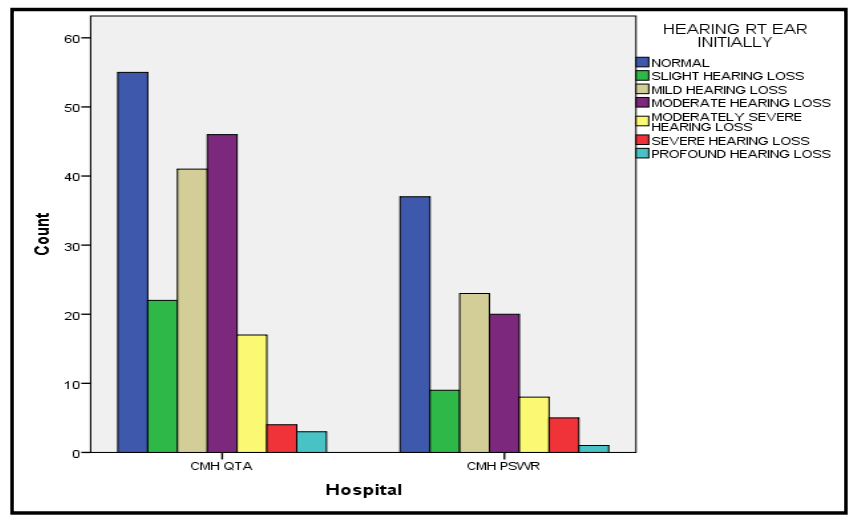

Figure-1: Degree of hearing loss initially.

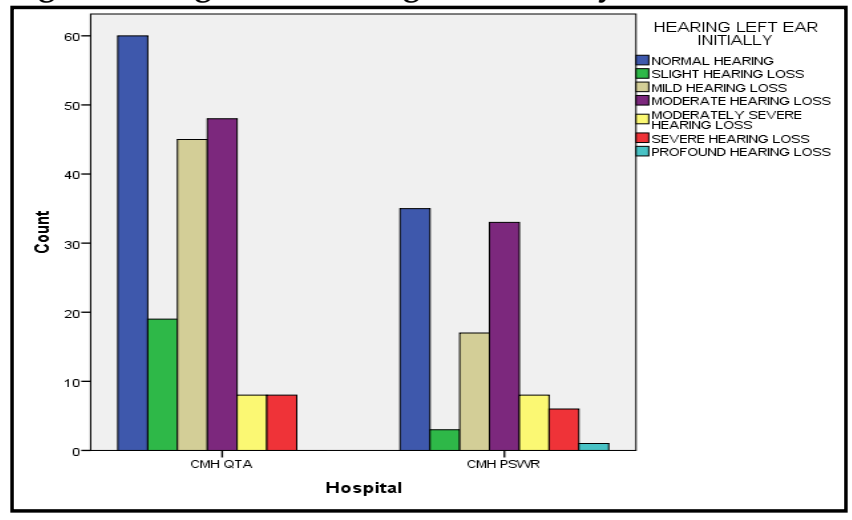

Figure-2: Degree of hearing loss at the end of six weeks.

In an explosion the explosive material is suddenly changed from a solid to gaseous form. This change results in a sudden increase in volume and a consequent rapid change in pressure. This massive pressure change generated travels in all directions with great velocity followed by a region of gas flow consisting of combustion products. These therefore, form two phases of the blast: a short positive pressure phase and a relatively long negative pressure phase. In addition there is an impulse noise that reaches the inner ear shortly after the blast wave $6,8,13,14$.

The bodily damage caused by a blast can therefore be by four different mechanisms: A primary blast injury, caused by the direct effect of the high pressure wave on the tissues. Secondary blast injuries caused by the fragments or debris propelled by the blast wind. Tertiary blast injury caused by blast wind knocking or blowing an individual into a solid object and quaternary blast injury which includes all other effects such as post traumatic stress disorder and burns $5,8,12$.

As an air containing organ the auditory system is most susceptible to blast wave associated damage. Such damages can be full range, affecting the region from the tympanic membrane to the inner ear, and lead to temporary and permanent losses of hearing sensitivity. These structural damages cause conductive hearing loss, sensorineural hearing loss or both. Damage to the tympanic membrane is a primary blast injury. Lungs and abdomen are the other organs which are sensitive to primary blast injury. Ear drum rupture can occur at pressures as low as $35 \mathrm{Kpa}$ while 105 Kpa pressure causes perforation in $50 \%$ of ear drums in adults2,4,5,12.

Although Pakistan has had a large number of bomb blasts over the recent years, little work has been done on determining the effect of blast trauma on the hearing outcomes of the affected population ${ }^{11}$. To authors knowledge this is the first study combining the data of two major terror struck cities. A number of studies have been performed internationally studying the outcomes of blast trauma on armed forces personnel serving in conflict zones however such patients are usually wearing some sort of protective head gear which can reduce the effect of noise induced trauma. We included only civilian population in our studies who were the innocent victims of a senseless attack. According to South Asian Terrorism Portal, Pakistan suffered 1321 civilian casualties in the regions of KPK and Baluchistan during the year 201311. Our study included a total of 504 patients initially which makes up $38.15 \%$ of the total civilian causalities in this region during the study period. Bias cannot be completely ruled out in our study as some patients who might actually have suffered severe trauma were unable to complete the questionnaire or participate in our study due to the extensive nature of associated injuries. 
Incidence of perforation as a result of blast trauma varies greatly depending upon the prior condition of the ear, the post trauma care of the damaged ear, the immune status of the patient and subsequent recovery of the patient, to name a few significant factors involved. The incidence of perforation varied from as low as $15(8 \%)$ to as high as $10(50 \%)$, similarly a study done by ChulHee Choi noted a $29 \%$ incidence of tympanic membrane perforation ${ }^{5}$. Our study had a comparable incidence of tympanic membrane perforation which was $37.45 \%$ at initial presentation. The chances of spontaneous perforation closure in our study was $24 \%$ which was comparable to another study by Remenschneider AK; 38\% ${ }^{19}$.

A study done by Cho et al studying the mechanism of hearing loss after blast injury using mice as animal models deter-mined that there is significant outer hear cell loss following blast trauma more so if there is tympanic membrane perforation which should result in a permanent threshold shift resulting in auditory dysfunction $^{17}$. In our study as well, chances of improvement in hearing were on an average of $17.9 \%$ and after perforation were of $8 \%$ only.

Another review study done by Perez et al documented the audiometric configuration following exposure to explosions. They noted that even though there was some recovery in hearing loss over a period of time however the audiometric configuration remained the same ${ }^{3}$. In our study it was observed that hearing loss was most in mild and moderate in pattern and overall chance of improvement was $17.9 \%$.

Our study had several drawbacks which can be improved upon in future studies. Firstly the follow up period can be increased; secondly most of the patients didn't have any previous hearing records, even though we were careful to exclude patients from the study based on history of hearing loss or any illness that might predispose to hearing loss however this bias could not be ruled out completely. Much work needs to be done regarding the impact of blast trauma on hearing in our country; we hope this article can be helpful in infusing fresh stimulus to our fellows to put much effort into his research.

\section{CONCLUSION}

The most common type of hearing loss following a blast trauma was mild to moderate. Chances of recovery of hearing following blast do existed. Much work needs to be done to study the impact of blast trauma on hearing in our country.

\section{CONFLICT OF INTEREST}

This study has no conflict of interest to be declared by any author.

\section{REFERENCES}

1. Van de Weyer PS, Praetorius M, Tisch M. Update: blast and explosion trauma. HNO 2011; 59(8): 811-18.

2. Aslier M, Aslier NGY. Analysis of Otologic Injuries Due to Blast Trauma by Handmade Explosives. Turkish Arch Otorhinolaryngol 2017; 55(2): 64-68.

3. Mizutari K. Blast-induced hearing loss. J Zhejiang Univ Sci B. 2019; 20(2): 111-15.

4. Ballivet de Regloix S, Crambert A, Maurin O, Lisan Q, Marty S, Pons Y. Blast injury of the ear by massive explosion: a review of 41 cases. J R Army Med Corps 2017; 163(5): 333-38.

5. Sandlin DS, Yu Y, Huang J, Zhang C, Arteaga AA, Lippincott JK, et al. Autonomic responses to blast overpressure can be elicited by exclusively exposing the ear in rats. J Otol 2018; 13(2): 44-53.

6. Okpala N. Management of blast ear injuries in mass casualty environments. Mil Med 2011; 176(11): 1306-10.

7. Choi $\mathrm{CH}$. Mechanisms and treatment of blast induced hearing loss. Korean J Audiol 2012; 16(3): 103-07.

8. Niwa K, Mizutari K, Matsui T. Pathophysiology of the inner ear after blast injury caused by laser-induced shock wave. Scientific Reports 2016; 6(1): 31754.

9. Lie A, Skogstad M, Johannessen HA, Tynes T, Mehlum IS. Occupational noise exposure and hearing: a systematic review. Int Arch Occup Environ Health 2016; 89(3): 351-72.

10. Ewert DL, Lu J, Li W, Du X, Floyd R, Kopke R. Antioxidant treatment reduces blast-induced cochlear damage and hearing loss. Hear Res 2012; 285(1-2): 29-39.

11. Liu L, Shen P, He T, Chang Y, Shi L, Tao S, et al. Noise induced hearing loss impairs spatial learning/memory and hippocampal neurogenesis in mice. Sci Rep 2016; 6(1): 20374.

12. Klamkam $P$, Jaruchinda $P$, Nivatwongs $S$, Muninnobpamasa $T$, Harnchumpol P, Nirattisai S, et al. Otologic manifestations from blast injuries among military personnel in Thailand. Am J Otolaryngol 2013; 34(4): 287-91.

13. Helfer TM, Jordan NN, Lee RB, Pietrusiak P, Cave K, Schairer K. Noise-induced hearing injury and comorbidities among postdeployment U.S. Army soldiers: April 2003-June 2009. Am J Audiol 2011; 20(1): 33-41.

14. Terrorism/South Asia Terrorism Portal.[internet] Satp.org.2016. Available from http://www.satp.org/.

15. Shah A, Ayala M, Capra G, Fox D,. Otologic assessment of blast and nonblast injury in returning Middle East-deployed service members. Laryngoscope 2014; 124(1): 272-77.

16. Wells TS, Seelig AD, Ryan MA, Jones JM, Hooper TI, Jacobson IG, et al. Hearing loss associated with US military combat deployment. Noise Health 2015; 17(74): 34-42. 
17. Cho SI, Gao SS, Xia A, Wang R, Salles FT, Raphael PD, et al. Mechanisms of hearing loss after blast injury to the ear. PLoS One 2013; 8(7): e67618.

18. Dougherty AL, Mac Gregor AJ, Han PP, Viirre E, Heltemes KJ, Galarneau MR. Blast-related ear injuries among U.S. military personnel. J Rehabil Res Dev 2013; 50(6): 893-04.
19. Remenschneider AK, Lookabaugh S, Aliphas A, Brodsky JR. Otologic outcomes after blast injury: the Boston Marathon experience. Otol Neurotol 2014; 35(10): 1825-34.

20. Mlynski R, Kozlowski E. Selection of Level-Dependent Hearing Protectors for Use in An Indoor Shooting Range. Int J Environ Res Public Health 2019; 16(13): 2266-82. 